\section{Isolation and Identification of a}

\section{Sexual Hormone in Yeast}

\author{
Akira Sakurai, Saburo Tamura, \\ Naohiko Yanagishima, * Chikashi Shimoda,* \\ Michio HaGIYA* and Narao TAKAO** \\ The Institute of Physical and Chemical Research, \\ Wako-shi, Saitama-ken \\ * Department of Biology, Osaka City University, \\ Osaka \\ **Kobe Women's College of Pharmacy, Kobe
} Received November 5, 1973

In heterothallic Saccharomyces cerevisiae, mating reaction takes place between opposite type cells designated $a$ and $\alpha$, and involvement of hormonal substances in this reaction have been confirmed. Levi ${ }^{1}$ first indicated secretion of a diffusible sex factor by $\alpha$ type cells, and Duntze et al. ${ }^{2,3}$ isolated a peptide named $\alpha$ factor that enhances cell elongation and inhibits DNA synthasis in a type cells. On the other hand, Yanagishima ${ }^{4}$ has found that $a$ and $\alpha$ type cells excrete hormone-like substances which specifically expand opposite mating type cells. This paper reports the isolation of $\alpha$ hormone secreted by $\alpha$ type cells and the identification of the substance as $n$-octanoic acid.

In this study biological activity of $a$ hormone was assayed by the following method. Haploid $a$ type cells were inoculated to the VHG medium composed of $5 \%$ glucose, $0.5 \%$ $\mathrm{KH}_{2} \mathrm{PO}_{4}, 0.2 \% \mathrm{MgSO}_{4} \cdot 7 \mathrm{H}_{2} \mathrm{O}, 0.5 \%$ peptone and trace amounts of vitamins. After shaking for $18 \mathrm{hr}$ at $26^{\circ} \mathrm{C}$, the cultured broth was centrifuged to collect cells, which were then washed and subjected to the Ficoll density gradient centrifugation. Small cells without buds were separated and inoculated to the VHG medium containing the test sample. After shaking for $3 \mathrm{hr}$ at $26^{\circ} \mathrm{C}$, grown cells were photographed using a microscopic projector. The cell volume $(V)$ was calculated by the epuation $V=a \times b^{2}, a$ being the long axis and $b$ the short one.
For the isolation of $\alpha$ hormone, haploid $\alpha$ type cells (T20 strain) were cultured stationarily on the VHG medium at $27^{\circ} \mathrm{C}$ for 2 days. The culture filtrate was extracted with methylene chloride at $\mathrm{pH} \mathrm{4,} \mathrm{and} \mathrm{the} \mathrm{extract} \mathrm{was} \mathrm{shaken}$ with $5 \%$ aqueous $\mathrm{NaHCO}_{3}$. The alkaline layer was acidified with dil. $\mathrm{HCl}$ to $\mathrm{pH} 3$ and re-extracted with methylene chloride to give an acidic fraction which showed biological activity to induce cell expansion in $a$ type cells. Then, this fraction was subjected to silica gel thin-layer chromatography (TLC) as a trial, and plates were developed with the following solvent systems: (1) isopropyl ether-acetic acid $(98: 2, \mathrm{v} / \mathrm{v})$, (2) ethyl acetateisopropanol-water $(65: 24: 11, \mathrm{v} / \mathrm{v})$ and (3) isopropanol-5 $\mathrm{N}$ ammonium hydoxide $(8: 2$, $\mathrm{v} / \mathrm{v})$. Each chromatogram was divided into five sections, which were eluted with ethyl acetate-methanol-acetic acid $(90: 10: 0.5)$ and bioassayed individually. The biological activity was detected at $R f 0.8 \sim 1.0$ with (1) or (2), and $R f 0.4 \sim 0.6$ with (3).

In order to purify the active principle, the acidic fraction was subjected to silica gel column chromatography by use of a solvent system of $n$-hexane-ethyl acetate-acetic acid $(190: 9: 1, v / v)$. Active fractions were combined and concentrated under reduced pressure to give a pale yellow oil. Silica gel TLC of the oil showed a spot at $R f 0.9$ with a solvent system of (1) and $R f 0.6$ with $n$-hexane-ethyl acetate-acetic acid $(80: 19: 1, v / v)$, when the plates were heated after spraying with chromic acid-sulfuric acid reagent. Gas chromatographic analysis using a column of DEGS$\mathrm{H}_{3} \mathrm{PO}_{4}(5-1 \%)$ on Chromosorb $\mathrm{W}$ indicated that the oil was a mixture of fatty acids mainly composed of $n$-decanoic and $n$-octanoic acids. The oil was further subjected to partition chromatography on Sephadex LH-20. After equilibration with the lower phase of $n$-hexanemethanol- $0.05 \mathrm{M} \mathrm{NaCl}(20: 15: 5, \mathrm{v} / \mathrm{v})$, the Sephadex column was developed with the upper phase of the same solvent system. The elution pattern together with the location of biological activity in eluates is shown in Fig. 1. Concentration of the active fraction gave a 
Table I. Mating Type-SPECificity in the EfFect of $n$-Octanoic Acid to Induce Cell Enlargement

Concentration of $n$-octanoic acid was $10 \mu \mathrm{g} / \mathrm{ml}$. In parentheses, $\%$ of control.

\begin{tabular}{|c|c|c|c|c|c|}
\hline \multirow{2}{*}{ Strain } & \multirow{2}{*}{ Mating type } & \multicolumn{2}{|c|}{ Small cells ${ }^{\alpha}$} & \multicolumn{2}{|c|}{ Unfractionated cells ${ }^{b}$} \\
\hline & & Control & n-Octanoic acid & Control & n-Octanoic acid \\
\hline $\mathrm{T} 20$ & $\alpha$ & $\begin{array}{c}70.6 \pm 1.3 \\
(100)\end{array}$ & $\begin{array}{c}68.5 \pm 1.8 \\
(97)\end{array}$ & $\begin{array}{c}66.8 \pm 2.8 \\
(100)\end{array}$ & $\begin{array}{c}70.3 \pm 2.7 \\
(105)\end{array}$ \\
\hline $\mathrm{T} 23$ & $a$ & $\begin{array}{c}83.7 \pm 2.0 \\
(100)\end{array}$ & $111.9 \pm 3.0$ & $\begin{array}{c}61.3 \pm 2.5 \\
(100)\end{array}$ & $\begin{array}{c}74.9 \pm 2.9 \\
(122)\end{array}$ \\
\hline $\mathrm{T} 21$ & $a$ & - & 一 & $\begin{array}{c}66.4 \pm 2.8 \\
(100)\end{array}$ & $\begin{array}{c}79.0 \pm 2.9 \\
(119)\end{array}$ \\
\hline $\mathrm{T} 22$ & $\alpha$ & - & - & $\begin{array}{c}71.9 \pm 3.1 \\
(100)\end{array}$ & $\begin{array}{c}70.3 \pm 3.0 \\
(97)\end{array}$ \\
\hline $\mathrm{H} 15$ & $\alpha$ & - & - & $\begin{array}{c}119.9 \pm 4.2 \\
(100)\end{array}$ & $\begin{array}{c}128.8 \pm 5.0 \\
(107)\end{array}$ \\
\hline
\end{tabular}

a) Small cells separated by the Ficoll density gradient centrifugation were used. The results are expressed as mean cell volume of mother cells with standard error.

b) Cells without the fractionation process were used. In this case mean cell volume of total cells including buds was measured.

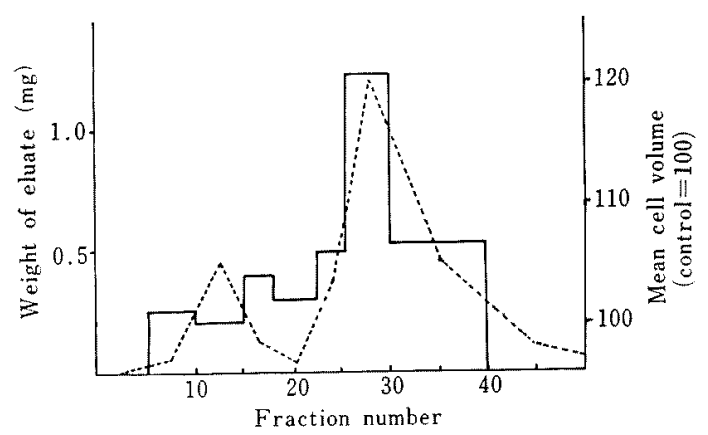

FIG. 1. Partition Chromatography of a Pale Yellow Oil from a Type Cells.

The column was eluted with a solvent system consisted of upper phase of $n$-hexane-MeOH-0.05 $\mathrm{M} \mathrm{NaCl}$ $(20: 15: 5, \mathrm{v} / \mathrm{v})$ to collect $5 \mathrm{ml}$ fractions. Fractions containing the same constituent (analyzed by gas chromatograph) were combined and bioassayed.

-, cell expansion activity for $a$ type cells.

---, weight of eluate after evaporation of the solvent.

colorless oil which showed a peak identical with that of an authentic sample of $n$-octanoic acid on gas chromatogram (a column of DEGS- $\mathrm{H}_{3} \mathrm{PO}_{4}$ was used for free acid and a column of DEGS for methyl ester). The mass spectrum of the free acid from the culture of $\alpha$ type cells showed peaks at $m / e 144\left(\mathrm{M}^{+}\right)$, 101, 73 and 60 verifying the validity of the identification. The yield of $n$-octanoic acid was around $2.6 \mathrm{mg}$ per liter of culture filtrate.

Then, the biological activity of an authentic $n$-octanoic acid to cause cell expansion was examined using various strains of $a$ and $\alpha$ types. As shown in Table I, the acid was active only for $a$ type cells, and mating typespecificity in the action was exactly the same as that depicted formerly for $\alpha$ hormone by Yanagishima. ${ }^{4}$ Furthermore, straight-chain fatty acids homologous to $n$-octanoic acid did not enhance cell expansion in both mating type cells. The details will be reported elsewhere.

Based on the result so far obtained, $\alpha$ hormone secreted by $\alpha$ type cells is considered to be $n$-octanoic acid. However, this simple acid is widely distributed in biological systems and, in fact, the amount of $n$-octanoic acid in the culture of $a$ type cells is roughly equal to that in the culture of $\alpha$ type cells. Accordingly, mechanism for the insensitivity of $a$ type cells to the acid secreted by themselves in culture media should be clarified in the future. Anyhow, it is worthy to note that $n$-octanoic acid specifically brings about cell expansion in a type cells of heterothallic $S$. cerevisiae.

Acknowledgement. We wish to thank Mr. Yukiharu Sato for his technical assistance during this study.

\section{REFERENCES}

1) J. D. Levi, Nature, 177, 753 (1956).

2) W. Duntze, V. Mackay and T. R. Manney, Science, 168, 1472 (1970).

3) W. Duntze, D. Stötzler, E. Bücking-Throm and S. Kalbitzer, Eur. J. Biochem., 35, 357 (1973).

4) N. Yanagishima, Planta (Berl.), 87, 110 (1969). 